\title{
Análisis de El Señor Presidente
}

La mejor novela de Miguel Angel Asturias (Guatemala 1899), y una de las mejores en toda la novelística hispanoamericana, es El Señor Presidente. Su composición fue lenta: de aquí las fechas 1922, 1925 y 1935 que quedaron señaladas al publicarse en 1946. No se menciona a ningún país, pero se sabe que Asturias elaboró alli recuerdos de su infancia y adolescencia, en Guatemala, bajo la tiranía de Estrada Cabrera. Como quiera que sea, nos proponemos analizar El Señor Presidente como obra de arte, no como documento histórico.

El título, tan irónicamente respetuoso, avisa la importancia que el señor presidente ha de tener dentro de la novela. Aparece sólo seis veces (V-VI, XIV, XIX, XXXII, XXXV, XXXVII), pero motiva todos los capítulos como Satán reina en todos los círculos del infierno y un dictador real domina todas las actividades de un país. Es, en realidad, un satánico dictador; y la novela, la descripción grotesca, trágica, deprimente y vergonzosa de una república centroamericana. Esta descripción, de indudable valor sociológico, tiene el mérito artístico de un estilo intensamente evocador, de una certera caracterización de numerosos hombres y mujeres y de una hábil composición argumental.

Por los muchos personajes y episodios entrelazados, la acción es compleja, pero no confusa. El idiota Pelele mata al más poderoso de los agentes de la dictadura, y este episodio inicial pone en funcionamiento la máquina infernal del dictador. Las escenas que vengan saldrán unas de otras en un movimiento ininterrumpido. Casualidad en el crimen del idiota, pero casualidad en la venganza del dictador. Hace asesinar al Pelele para ocultar su culpabilidad y asi poder acusar a dos políticos caídos en desgracia a quienes ahora quiere liquidar: Canales y Carvajal. El dictador ordena a su favorito, Cara de Angel, que avise a Canales: el plan es matarlo en el acto de huir. Pero Canales consigue huir y Cara de An. gel secuestra a su hija Camila. Sólo que se enamorará y, al casarse con ella, perderá el favor del dictador, quien le prepara una atroz celada: 
le encarga públicamente una misión a los Estados Unidos, lo hace detcner secretamente, lo reemplaza con un "doble" (que viaja con documentos apócrifos y finge desaparecer como un prófugo para dejar en el airc falsas pistas) lo encierra durante años en una asquerosa mazmorra hasta que, enfermo, le hacen creer que Camila es la querida del dictador $y$ Cara de Angel -el personaje mejor creado en toda la novela- muere. Esta es la hebra principal, pero se entreteje con varias otras en una trama bien ceñida, bien diseñada. Por ejemplo: la hebra Auditor-Vázquez-Rodas-Fedina-Chón-Diente de Oro-Fanfán. No hay hilachas sueltas, todo está anudado; y aún los personajes menores - como el estudiante y el Sacristán- aparecen y reaparecen como puntadas en una costura.

La narración se divide en tres partes: capítulos I-XI, que transcurren del 21 al 23 de abril de 1916; XII-XXVII, del 24 al 27; XXVIII$\mathrm{XLI}$, donde los pasos se alargan en "semanas, meses, años", sin perder la dirección. El epílogo, breve y anticlimático, no está fechado pero se supone que transcurre poco después porque la situación política no ha cambiado y todavía están demoliendo el Portal donde se cometió el crimen del primer capítulo. Dejando de lado las retrospecciones - que por ser procesos mentales de los personajes no alteran el orden de los acontecimientos reales- la narración avanza con normalidad: únicas excepciones en esta progresión lineai son el capítulo XXIII, intercalado a destiempo, y los capitulos XXIV y XXV, que barajan desordenamente las horas.

Asturias ha elegido la perspectiva del autor-omnisciente, y los ojos de este autor-omnisciente van desplazándose como los de una cámara cinematográfica para seguir ya a un personaje, ya a otro, de tal mancra que no perdamos de vista la significación de escenas simultáneas o sucesivas. No sólo el autor-omnisciente nos muestra todo lo que cstá ocurriendo en esa sociedad, tanto lo público como lo privado, sino que también nos deja asomar a los pensamientos más íntimos de sus personajes, aun al inarticulado fluir de la subconsciencia durante el cnsimismamiento, el ensueño, cl delirio y la locuta. Sea que el autor psicoanalice a sus personajes, deje que sus personajes se autoanalicen o nos los revele en sus propios monólogos interiores (a veces tan directos como los de Joyce), la novela es muy subjetiva. Es que el autor-omnisciente lo ha poetizado todo. La excelencia de El Señor Presidente, sobre todo si, la comparamos con otras novelas que se escribieron en Hispanoamérica por los mismos años, se debe precisamente a la fusión de mundo social y mundo psicológico dentro de la fantasía de un autor-omnisciente que no renuncia a su propia visión poética. 
Asturias no describe con la impasibilidad de un realista ni interviene en la acción desde fuera: poquísimas veces rompe la unidad interior de la novela con reflexiones extemporáneas. Tampoco propone una tesis, ni marxista, ni liberal, ni católica. No se ven, en el horizonte de la novela, las nociones de dignidad del proletariado ni de progreso indefinido ni de democracia reformista ni de heroismo de la conciencia autónoma. El único programa de justicia social que se menciona lo oimos en boca del general Canales, que al huir piensa en revoluciones, más por desesperación y resentimiento que por heroísmo o principios políticos (XXVII). La única voz optimista es la del estudiante cuando, en las sombras de la cárcel, expresa su voluntad revolucionaria y un viejo maestro, también preso, comenta: "ino todo se ha perdido en un pais donde la juventud habla así!" (XXVIII). Hay frases que denuncian, que condenan, que se indignan ante la injusticia. Pero la dictadura no está pintada como el resultado de un proceso histórico moral, social, político, económico que es posible corregir con soluciones conocidas, sino más bien como un caos administrado por una cabeza demoníaca. Irónicamente, no es un ciudadano responsable sino un mendigo idiota -Pelele- quien, sin darse cuenta de lo que hace, mata al coronel Parrales Sonriente el brazo armado de ese régimen de terror. Irónicamente, no es un intelectual ni un político, sino el humilde Tío Fulgencio quien da la frase-síntesis de la situación nacional: "la única ley en ésta es la loteria: por loteria cae usted en la cárcel, por lotería lo fusilan, por lotería lo hacen diputado, diplomático, presidente de la República, general, ministro... todo es por loteria" (XV). La vida política, es, pues, tan caótica como una loteria, y el dictador es quien da los golpes del azar: "Hasta de diosa ciega tengo que hacer en la lotería", dice (XXXVII). El autor-omnisciente (o sea, el ojo que Asturias ha puesto dentro de la novela) no sólo no se distrae proponiendo una tesis salvadora, sino que, con su intriga novelística, refuerza la intriga política del dictador.

La materia está vista y moldeada, pues, por un artista. De aquí el tono poético de la novela. Aquella materia, si la pensáramos en la realidad, sería fea. Mendigos, borrachos, venéreos, avaros, corrompidos, aduJones, cobardes, hipócritas, piojosos, prostitutas, homosexuales, traidores, mentirosos, ladrones, imbéciles, asesinos, brutos; castigos, muertes, putrefacción, vómitos, corofagia; miseria, sordidez, venalidad; en fin todas las fealdades de la vida real. Pero el artista toma posesión de esa realidad, la penetra con su visión, le da forma y la convierte en belleza. Porque los términos "beilo", "feo" no se refieren a los objetos, sino a nuestra actividad mental. "Feo" es el desfallecimiento de la fuerza crea- 
dora, la distensiòn del espiritu, el fracaso de la capacidad expresiva, el hueco que en la voluntad estética queda sin llenar, el trozo de realidad que percibimos pero sin subordinarlo a un enérgico sentido de valores. "Bello" es lo contrario: el descubrimiento de una sorprendente novedad que abre la originalidad del ánimo de un artista y lo hace desenvolverse y trascender hacia posibles valores. Tremenda es la realidad de que se ha servido Asturias para su novela; pero más tremenda es su imaginación. $Y$ porque la imaginación lo toca todo, todo queda transfigurado en imágenes. A veces imágenes rendidas con estilo impresionista, es decir, que analizan las percepciones sensoriales sin explicarlas por sus causas, sea para describir la intimidad mediante comparaciones con la naturaleza ("Sus tías, unas repugnantes $[\ldots]$ o la besaran sus tías sin levantarse cl velito del sombrero, sólo para dejarle en la piel sensación de telaraña pegada con saliva", XII) sea para animar la naturaleza con las proyecciones de la intimidad ("Los árboles enloquecidos por la comezón de los trinos y sin poderse rascar", XII). A veces imágenes tendidas con estilo expresionista, es decir, que en lugar de limitarse a recibir los estimulos de la realidad deforman la indole natural de los objetos y sobreponen a la realidad una manera personal de vivir, sentir, fantasear, recordar, pensar y querer: "A las detonaciones y alaridos del Pelele, a la fuga de Vázquez y su amigo, mal vestidas de luna corrían las calles sin saber lo que había sucedido [...] Las calles asomaban a las esquinas preguntándose por el lugar del crimen y como desorientadas unas corrian hacia los barrios céntricos y otras hacia los arrabales"... etc. (VIII).

En ambos estilos Asturias descuella por la energía, pero lo que dio a El Señor Presidente una posición singular en las letras hispánicas fue, sobre todo, su expresionismo. Y en este surtidor de su estilo es donde to "feo" natural sc hizo "bello" artístico. Asturias no quiso formular una tesis extetior a la novela, pero dentro de la novela, en cambio, con la ironía, el sarcasmo, la exageración, la caricatura, la crítica intelectual, la alcgoría, el esperpento, el propósito moralizador y reformista logtó simbolizar una redonda concepción de la vida. $Y$ por la vigorosa fuerza de esa filosofía personal aun los episodios más tepugnantes - como el vómito del dictador sobre Cara de Angel, como la lata donde da lo mismo comer que defecar- sorprenden como nuevos descubrimientos en una aventura que va creándose a sî misma.

Las frases brillan porque hasta la inmundicia ha sido puesta en estado de combustión. Y si las juntáramos aqui -cosa que no podemos hacer por falta de espacio- tendríamos una antología no sólo del lirismo de Asturias sino también de las literatutas de vanguardia que siguic- 
Ion después de la primera guerra mundial: expresionismo, cubismo, crencionismo, dadaismo, superrealismo.

La concepción del mundo de Asturias ha seleccionado de la realidad una triste materia para elaborarla novelísticamente. Una vez en el pro. ceso mismo de la elaboración novelística, su visión lírica ha ido levantando todas las cosas. El lado lingüístico de esta ascención puede obselvarse en su manera de manejar las palabras. Podríamos graduar, con escalones, los niveles por los que va subiendo la lengua: sonidos anteriores a la palabra articulada, onomatopeyas, jitanjáforas, regionalismos puestos en las bocas más incultas del vulgo, neologismos, sorprendentes aciertos en la palabra justa, finas creaciones verbales, metáforas. Y ya en este supremo nivel de la metáfora, Asturias canta y piensa con su "sien de alondra".

Harvard University

ENRIQUE ANDERSON IMBERT 
